\title{
5
}

\section{The Aesthetics of Sympathy: \\ George Eliot's Telepathy Machine}

... for we all of us, grave or light, get our thoughts entangled in metaphors, and act fatally on the strength of them.

—George Eliot, Middlemarch

$\mathrm{T}_{\mathrm{h}}$ he foregoing chapters have examined the rhetoric and politics of aesthetics from a vantage granting a narrower focus to our investigation than its conscience finally allows. Not that any other vantage presented itself; furthermore, the sequence of readings pursued up to this point has allowed for a satisfying degree of internal coherence. The problem of the Bildungsroman, which we established as an overdetermined locus of tension within literary studies, leads to the problem of reading Wilhelm Meisters Lehrjahre; and the linguistic, thematic, and historical proximities between this novel, on the one hand, and the theoretical writings of Kant, Schiller, Schlegel, and Hegel, on the other, allowed our reading of Goethe's text to engage and displace the discourse of aesthetics in ways visibly relevant to the conundrum of the Bildungsroman. The difficulty we then encounter springs from the peculiar nature of the object in question. Since the Bildungsroman is an aestheticized symptom of literature's uncertain manifestation of itself as criticism, it exists only as an exemplary instance of the ghostliness of aesthetics itself; and part of what we signal in these figures of ghosting and haunting is an ongoing process of framing that is also its own rupture. Aesthetics itself, as we saw in chapter 1, is a name for this paradox; and a critique of aesthetics is not only doomed to repeat the instability of its object, but furthermore obtains critical purchase only in and through this repetition. What this means in the case at hand is that our focus on the Bildungsroman's exemplary text, Wilhelm Meister, is at once necessary, productive, and misleading to the extent that aesthetics thereby takes on the appearance of being a "German" problem. A specific constellation of problems may in all fairness be said to haunt both the culmination of the "meta- 
physics of the subject" in nineteenth-century German philosophy and the culmination of an aesthetic notion of politics in twentieth-century German fascist ideology. In terms of our more limited critical engagement here, the Wanderjahre's deconstruction of pragmatized Bildung has particular force as a critique of the intensely aestheticized politics of the Nazi era. The very force of that critique, however, will at a certain point become profoundly misleading. As discussed in this book's opening chapter, aesthetic discourse inheres in the fabric of modern Western culture, which is in part why the notion of the Bildungsroman has proved so seductive and volatile.

Goethe's texts thus retain a legitimate exemplarity in this context while also needing to be abandoned at a certain point for other significant literary formulations of the possibility or impossibility of a Bildungsroman. Where one intervenes in such a complex, overdetermined, and phantasmatic history becomes a matter of strategy. The works of George Eliot provide us with a literary interrogation of aesthetics usefully distant and different from Goethe's, though still recognizably engaged with the Schillerian tradition that Matthew Arnold inherits and bequeaths to Anglo-American literary institutions. ${ }^{1}$ It is a commonplace that Arnoldian humanism finds a close literary analogue in Eliot's novels; but it is equally a commonplace that Eliot anticipates Freud, whose earliest publications begin to appear only a decade after Daniel Deronda (1876): if her novels seek ethical and political ground in aesthetic pedagogy, they do so in a language of psychological and sociological nuance proper to their era of literary representation. Meanwhile, Eliot's thematization of the "sympathetic imagination" returns us to topics central to any study of aesthetic ideology. The link between pathos and poetics goes back, of course, to classical issues of mimesis, identification, and katharsis, but a more specific link emerges in post-Renaissance Europe with the development of a language of passion that, from Shaftesbury through Rousseau, Hume, Burke, and Kant, went into the making of the modern notion of "aesthetics" per se.

Sentimentalism, which here denotes not just the era of Sterne, Rousseau, and Klopstock, but also, more generally, a certain focus on and valorization of affect that remains a recognizable literary idiom until the First World

1. Eliot, of course, like Carlyle and Arnold, was immersed in German literature and culture, and is in fact the author of an essay titled "The Morality of Wilhelm Meister" (July 1855), in which she, like many critics before and since, registers unhappiness with the novel's flagrantly fictional ending: "Just as far from being really moral is the so-called moral dénouement, in which rewards and punishments are distributed according to those notions of justice on which the novel-writer would have recommended that the world should be governed if he had been consulted at the creation." Essays of George Eliot, ed. Thomas Pinney (London: Routledge and Kegan Paul, 1963), 145. Essays from this edition will be referred to by page number preceded by "Pinney." 
War, may be distinguished from earlier discourses of the passions by its implicit or explicit claim to universality. As opposed to the melancholic, whom he may occasionally resemble, the man of feeling has a purposive structure bracing his sentiment: even on the occasions when he knows not why he is so sad, he knows, at least in theory, that he is in communication with essential humanity. The notion of aesthetic disinterestedness emerges in close relation with that of the universality of sentiment in the eighteenth century, and when Kant defines aesthetic judgment he does so by theorizing the formalization of affect itself: a judgment is "called aesthetic precisely because the basis determining it is not a concept but the feeling (of the inner sense) of that accordance in the play of the mental powers insofar as it can only be sensed." 2 Sentiment is pure communication, both between subjects and within the subject itself. It is the origin of language, and it is what remains when language fails. And thus sentiment is also, of course, senseless: a mute and irrational force of desire, at once effeminizing and a threat to official femininity, the stuff of Gothicism and romance, mob violence and revolution.

Furthermore, in becoming a dream of pure communication, sentiment not only vacillates between formal ideality and formless matter but becomes yet another figure for the linguistic processes it supposedly founds and transcends. On the one hand, sentiment registers as a somatic experience-and a certain equivocal valorization of the body traditionally marks sentimental discourse-but on the other hand, sentiment is never simply somatic. As an attitude of consciousness, it involves representation and identification: sentiment is sympathy. Irreducibly tied to the interplay of self and other, sentiment, as sympathy, is "always already an aesthetic experience," as David Marshall insists: one that can only "take place within the realm of fiction, mimesis, representation, and reproduction." 3 Despite its-usually explicit-hostility to poetics or rhetoric, the discourse of sentiment is necessarily also a discourse of tropes. Edmund Burke's definition of sympathy in the Enquiry may in this respect be taken as typical:

For sympathy must be considered as a sort of substitution, by which we are put in the place of another man, and affected in many respects as he is affected. . . . It is by this principle chiefly that painting, and other affecting

2. Immanuel Kant, Critique of Judgment, trans. Werner S. Pluhar (Indianapolis: Hackett Publishing Co., 1987), 75 (sec. 15). Aesthetic affectivity, in other words, lies "not in a sensation of the object" but in subjectivity itself, which in turn guarantees taste as, precisely, a common sense. See Terry Eagleton, The Ideology of the Aesthetic (Oxford: Blackwell, 1990), 13-69, for a narrative of the origins of aesthetics that emphasizes the importance of sentimentalism.

3. David Marshall, The Surprising Effects of Sympathy: Marivaux, Diderot, Rousseau, and Mary Shelley (Chicago: University of Chicago Press, 1988), 21. 
arts, transfuse their passions from one breast to another, and are often capable of grafting a delight on wretchedness, misery, and death itself. ${ }^{4}$

Pleasure is no longer the product of representation or mimesis per se, but of the occurrence of a "sympathy" structured like representation or, more precisely, like metaphor: "a sort of substitution, by which we are put in the place of another man." Even in this brief citation one recognizes some of the characteristic turns of sentimental writing: a Gothic idiom of rapture and displacement, complemented by figures at once organic and non-natural, as the arts "transfuse" passions and thus "graft" delight onto pain and death. By the very fact that it is a substitutive process, sympathy incorporates an unnatural, technical element into its naturalness, thereby ensuring that a certain violence will always qualify sympathy's occurrence. Sympathy seizes and dis-places: through an unnatural excess of naturalnessregistered in the Burke passage as the supplemental activities of transfusion and grafting-sympathy destabilizes and threatens to destroy the subject it defines. Sentiment, a dramatic version of what Jacques Derrida has called the dream of self-presence as a "touching-touched," turns into the agent of the self's undoing, precisely because sentiment must always also be communication, even when reduced to the self-communion of subjectivity. 5

Ethical and representational systems predicated on sympathy will consequently be precarious. Even before attending to their rhetorical complications, one encounters difficulties: sympathy's emphasis on empirical experience threatens to turn the self into an accumulation of accidents, while its reliance on representation and identification means that ethical judgment becomes flavored with voyeurism and sadomasochism, since sympathy requires for its existence the spectacle of an other's suffering. But the discourse of sympathy also possesses great resiliency and appeal; though sentimentalism per se is a recognizably historical phenomenon, the sentimental inheritance continues to manifest itself in the interstices of contem-

4. Edmund Burke, A Philosophical Enquiry into the Origin of Our Ideas of the Sublime and the Beautiful, ed. James T. Boulton (New York: Columbia University Press, 1958), 44.

5. Jacques Derrida, Of Grammatology, trans. Gayatri Spivak (Baltimore: Johns Hopkins University Press, 1976). In the British tradition, William Hazlitt's Essay on the Principles of Human Action: Being an Argument in favour of the Natural Disinterestedness of the Human Mind (1805) provides a particularly rich account of the paradoxes of sympathy. Individual identity, as Hazlitt sees it, for instance, depends on the self's proleptic identification with itself: "The imagination, by means of which alone I can anticipate future objects, or be interested in them, must carry me out of myself into the feelings of others by one and the same process by which I am thrown forward as it were into my future being, and interested in it." The Complete Works of William Hazlitt, ed. P. P. Howe (London: J. M. Dent, 1930), 1:1-2. I shall be examining versions of this paradox in Eliot's work. 
porary culture and theory, most notably in what appears to be a persistent temptation to locate in the "body" a reservoir of affective meaning. ${ }^{6}$ It is thus important to take this tradition seriously and follow, so far as possible, its unfolding. My reading of Goethe involved a brush with sentimental discourse in the orbit of Mignon-and it is certainly no accident that Mignon, the locus of sentimental investment, serves as the vehicle of semiotic stress. But it must also be said that the Lehrjahre's disconcerting ironization of affect and denaturalization of the body takes place within a rather ancien régime blend of picaresque emplotment and sentimental tableaux. Despite the novel's baroque elaboration of oedipal structures, it has little of the Gothic chiaroscuro so prevalent in the English tradition from Richardson on. For any number of cultural, historical, and personal reasons-in this matter one clearly should not discount Goethe's post-Werther hostility to the sentimental tradition of Klopstock and the Jacobis-the Lehrjahre cannot really be said to be seeking to contribute to the construction of the richly psychologized "desiring subject" that the nineteenth-century realist novel was to be able to offer Freud.

George Eliot's work explores the strengths and instabilities of a sentimental aesthetic with a rigor and depth that owes much to a confluence of historical factors. The development of the life sciences allowed her to appeal to a complex organicism, while the resources of the high Gothic tradition provided her with the means to represent historical events or structures in psychological and protopsychoanalytic terms. In approaching these novels we enter what Eve Sedgwick has called the Victorian novel's "warm space of pathos and the personal," where the public dimensions of culture are translated into "the supposedly intrapsychic terms of desire and phobia," thereby composing the texture of the literary form that we rather misleadingly call realism. ${ }^{7}$ At stake, however, in Eliot's text no less than in Goethe's, is the possibility of aesthetic history.

6. The Gothic and sentimental traditions not only continue to shape, mutatis mutandis, "popular" and mass-marketed culture but have also left their mark on more elite cultural activities. Eagleton's The Ideology of the Aesthetic, which begins with the claim that "aesthetics is born as a discourse of the body" (13) and closes with eudaemonic invocations of the body as the "natural" base for "creative self-making" (410), is deeply marked by the empiricist and sentimental tradition for all its putative Marxism, and its most successful chapters are those focused on British eighteenth-century material. One thinks too of Elaine Scarry's influential The Body in Pain: The Making and Unmaking of the World (New York: Oxford University Press, 1985). The body has also, given its various ideological charges, served as a locus for critical historicization and demystification: for a study that complements the concerns of the present chapter, see Mark Seltzer, Bodies and Machines (New York: Routledge, 1992) (see 101-3 and 205-6 n. 18, for a concise critique of Scarry). For a survey of current work on nineteenth-century discourses of the body, see the special issue of Representations 14 (1986), on "Sexuality and the Social Body in the Nineteenth Century," ed. Catherine Gallagher and Thomas Laqueur.

7. Eve Kosofsky Sedgwick, Between Men: English Literature and Male Homosocial Desire (New York: Columbia University Press, 1985), 67, 119. The much-disputed term "realism" has no particular privilege in the present discussion, but from the perspective of a critique of aesthet- 
"The greatest benefit we owe to the artist, whether painter, poet, or novelist," Eliot wrote in "The Natural History of German Life," "is the extension of our sympathies" (Pinney, 170). The fiction she began writing in the wake of that assertion ceaselessly reflects on and reaffirms it; and by the time of her last, great novels, Middlemarch and Daniel Deronda, her aesthetic of sympathy had itself become exemplary of the extension it preached, drawing its metaphors to such telling effect from so many discourses that the gap between the domestic world of affective interchange and the public world of politics and history will often seem to have been at least provisionally overcome. The governing trope of the individual as psyche and organism is at once affirmed and subtly transcended, as in the famous passage in Middlemarch in which the text articulates the terms of Dorothea's sympathetic Bildung:

We are all of us born in moral stupidity, taking the world as an udder to feed our supreme selves: Dorothea had early begun to emerge from that stupidity, but yet it had been easier to her to imagine how she would devote herself to Mr Casaubon, and become wise and strong in his strength and wisdom, than to conceive with that distinctness which is no longer reflection but feeling - an idea wrought back to the directness of sense, like the solidity of objects-that he had an equivalent centre of self, whence the lights and shadows must always fall with a certain difference. ${ }^{8}$

While the text emphasizes the self's privileged status throughout the educative process-a process leading from the stupidity of the "supreme self" of infantile narcissism to the recognition of difference as the other's "equivalent centre of self" - the trope of the udder suggests that even narcissism must nourish itself on otherness ("the world"). If Middlemarch has one overarching theme, it is the shaping of character, action, and destiny by environment. Dorothea, a Saint Theresa born too late, can accomplish only what the novel's final paragraph designates "unhistoric acts" (896): as a nineteenth-century woman she can find for herself "no epic life," being "helped by no coherent social faith and order which could perform the function of knowledge for the ardently willing soul" (25). Despite her inherent saintliness or heroism, she cannot help diverting her energies into a

ics, John Bender's definition of realism is suggestive: "a fine, observationally oriented, materially exhaustive grid of representation that accounts for behavior, in fact constructs it, in terms of sensory experience." John Bender, Imagining the Penitentiary: Fiction and the Architecture of Mind in Eighteenth-Century England (Chicago: University of Chicago Press, 1987), 11.

8. George Eliot, Middlemarch: A Study of Provincial Life (Harmondsworth: Penguin, 1965), 243. Subsequent references are to this edition. 
romance plot, her range of motion being confined to the unhistoric act of marriage.

But though the novel emphasizes that historical constructions of gender (and genre) define the forms of being and doing open to Dorothea, the organic metaphors controlling Middlemarch's official themes work to absorb her into a total historical process. Eliot's organicism has remained a potent influence in determining how her texts are read and taught thanks in large part to the subtlety with which her texts rework the classical figure of the text as body. ${ }^{9}$ It is possible to argue, for instance, that in Eliot's novels, as in George Henry Lewes's Problems of Life and Mind, consciousness "is not an agent but a symptom," an element of the total "mind," which, according to Lewes, is the activity of the whole organism. ${ }^{10}$ Actions and details lost to consciousness are grounded and stored in the body, or in the trope of the body: thus Bulstrode's ambiguous murder of Raffles emerges out of "misdeeds" that "were like the subtle muscular movements which are not taken account of in the consciousness, though they bring about the end that we fix our mind on and desire" (Middlemarch, 740). More dramatically and positively, Will seizes Dorothea's hand "with a spasmodic movement" under the external stimulus of a providential flash of lightning ("which lit each of them up for the other-and the light seemed to be the terror of a hopeless love" [868]); the body obeys a desire that consciousness evades or represses, or has not yet fully assimilated ("What she was least conscious of just then was her own body" [865]). Lewes's word "mind" is the appropriate term for the totality of this embodied self, since the body pursues ends dictated by an intention; however, thanks to its body, consciousness finds itself part of a larger entity capable of recording unperceived sensations, thinking "unconscious" thoughts, and acting out repressed truths or memories, as when Tito, in Romola, for instance, reacts involuntarily to the sight of his father, Baldassare, and thereby sets in motion the narrative sequence that will reveal and punish his own moral turpitude. The body is a reservoir of identity surpassing the conscious "self" while remaining controlled by

9. Interest in Eliot and science and bodies goes back to the publication of Middlemarch. One contemporary reviewer, Sidney Colvin, suggested a link between Eliot's "scientific consciousness" and her description of the bodies and bodily tics of characters; see David R. Carroll, ed., George Eliot: The Critical Heritage (London: Routledge, 1971), 331-38, esp. 334. Since the 1970s, criticism on Eliot's literary appropriations of science, medicine, and the body has proliferated, and the invocation of these categories not infrequently serves an effort to ground the textual complications offered by these novels. See in particular George Levine, "George Eliot's Hypothesis of Reality," Nineteenth-Century Fiction 35 (1980): 1-28, and Sally Shuttleworth, George Eliot and Nineteenth-Century Science: The Make-Believe of a Beginning (Cambridge: Cambridge University Press, 1984).

10. George Henry Lewes, Problems of Life and Mind, 3d series (London, 1879), 2:365; cited in Shuttleworth, George Eliot and Nineteenth-Century Science, 20. 
the trope of selfhood; and thus the body tropes the insertion of the self into the larger intentional structure of history.

Consequently, from the point of view of the self, the body is a privileged trope for history or narrative. Lydgate's quest for the "primitive tissue" may be as doomed as Casaubon's for the "key to all mythologies"; but if Lydgate has frequently been taken as a figure representative of the kind of imagination that the narrator of Middlemarch valorizes, this is in part because his fascination with the body and its "tissues" returns us etymologically as well as thematically to the semantic field of texere, weave, and connects through Lydgate's mentor, Bichat, to histology and hence histos, web, the "particular web" of Eliot's organic, realist, non-Fieldingesque novel (170). To the guiding metaphor of the web, as J. Hillis Miller points out, "must be added the metaphor of the stream": "This figure is homogeneous with the figure of the web in that flowing water, for Eliot, is seen as made up of currents, filaments flowing side by side, intermingling and dividing. Flowing water is, so to speak, a temporalized web."11 It is also a trope homologous with the body as a constantly growing or changing system of circulation. History, inscribing itself within bodies, is itself a body to the extent that the metaphors of web and current convey a promise of telos and form, and to the extent that "unhistoric acts" can be absorbed into history just as unperceived sensations or unacknowledged meanings are recorded by the embodied self. Middlemarch's closing paragraph has the resonance it does because its dignified melancholy is compounded with affirmation:

Her finely-touched spirit still had its fine issues, though they were not widely visible. Her full nature, like that river of which Cyrus broke the strength, spent itself in channels which had no great name on the earth. But the effect of her being on those around her was incalculably diffusive: for the growing good of the world is partly dependent on unhistoric acts; and that things are not so ill with you or me as they might have been, is half owing to the number who lived faithfully a hidden life, and rest in unvisited tombs. (896)

Dorothea's failure mingles with the anonymity of "the number" whose unhistoric acts help fuel history's melioristic movement, and she is taken up into the body of history through a death that assimilates her to an eschatology. The domestic sphere of sentiment, of narrative realism, and of unhistorical and feminine acts thus finds articulation with history through the "natural" medium of the textual body.

11. J. Hillis Miller, "Optic and Semiotic in Middlemarch," in The Worlds of Victorian Fiction, ed. Jerome H. Buckley (Cambridge: Harvard University Press, 1975), 132. 
The subtlety of this figurative system becomes even more impressive when we examine its ethical correlative. If "the growing good of the world" partly depends on agents whose selfhood is effaced in the anonymity of the unhistoric, then this loss of self acquires a moral logic and can be attached to the ethical task of overcoming narcissism. As exemplified in Dorothea's effort to come to terms with Mr. Casaubon in Rome, the subject's education or Bildung consists in a movement from narcissism to sympathy, from a natural state ("taking the world as an udder") to a fully cultural one. Shocked into awareness of otherness by the other's desire, the self accedes to sympathy by sacrificing its narcissistic projections and recognizing the other's "equivalent centre of self" - that is, if the self is capable of this painful itinerary. Eliot's reformulation of the sentimental tradition is powerful in part because of her unsentimental focus on the difficulty of genuine sympathy. Sympathy requires energy, and Eliot's rhetoric here is usually quantitative: characters such as Romola or Dorothea are "ardent" enough to profit fully from the shocks they receive, while characters such as Mr. Casaubon have rather a "proud narrow sensitiveness which has not mass enough to spare for transformation into sympathy" (313). A sympathetic education thus consists in a check to the self resulting in a self-overcoming figured as growth or expansion. And the result is an unhistoric act that, contributing to the "growing good of the world," rejoins the greater current of history: thus the loss and gain of the sympathetic itinerary mirrors the loss and gain by means of which this itinerary is rendered historical.

We may step back for a moment and observe that this elegant and subtle figurative system constitutes an aesthetics in the sense we have given this term in previous chapters: that is to say, it is a historical and political model. The act of sympathy may be resolutely empirical, and is certainly by definition an interested act in Kantian terms; yet in performing it, the subject of sympathy nonetheless becomes representative of an essentially human potential. In theory, one might say, the subject of sympathy is ready to sympathize with anyone-or at least with anyone actually or potentially human. Sympathy is ultimately homologous with aesthetic judgment as the proleptic articulation of the individual subject with universal man. Consequently, art, or culture in an Arnoldian sense, proposes itself as the natural vehicle for the "extension of our sympathies." Culture is the public equivalent of private sympathetic acts. And thus the private itinerary from natural egoism to mature sympathy replays itself in historical form as the ascent from savagery to culture that we have seen to compose the narrative of aesthetic ideology. In "The Natural History of German Life," for instance, Eliot's self- and class-centered German peasant is bound to repetitive narrowness-not unlike Mr. Casaubon, paradoxically enough: "[C]ustom holds with him the place of sentiment, of theory, and in many cases of 
affection" (Pinney, 279). Untouched by the abstracting fires of culture, the peasant has no sense of universality and cannot perform the symbolic sacrifice of self that would grant him comprehension of "the rights of man" (283); like Felix Holt's working-men, he will need to grow slowly into entitlement through the diffusive effects of middle-class sympathy and the novels, poems, paintings, and middle-class politicians that transmit it. The organic model of history we find in Middlemarch thus remains a version of aesthetic history in all essential respects, which is to say that for all its putative modesty it remains a history of the subject, as the totalizing category of "Mind" in G. H. Lewes's terminology makes clear. Organicism, as Philippe Lacoue-Labarthe and Jean-Luc Nancy comment, is "essentially auto-formation, or the genuine form of the subject," which is also to say that an organic history will always eventually reveal itself, as J. Hillis Miller points out, to be a tributary of Hegel's claim that "at the bottom of history, and particularly of world history, there is a final aim." 12

Precisely at this point, however, a certain degree of tension creeps into the organic-sympathetic aesthetic. If history is finally the self-disclosure of the Subject, then history should occur in and through a dialectic of recognition and internalization, as in the full Hegelian model: a dialectic that in fact has little in common with the temporal and ontological continuity ascribed to the natural world, just as and for the same reason that sympathy cannot be reduced to its somatic component. The painful shock and expansion of the sympathetic education ought in principle to be the engine of history, and here Eliot's texts may be said to retreat from the consequences of their own claims. A historical model as fraught with conflict, misunderstanding, and pain as a sympathetic education might still fall into an aesthetic paradigm, but would certainly involve more stress than one typically associates with the official version, at least, of George Eliot's meliorism. History, in Middlemarch, masquerades as a process of continuous, body-like growth only to the extent that the novel largely restricts its exploration of the drama of consciousness to the domestic sphere, confining the violence and discontinuity characteristic of stories of consciousness to the plane of the unhistoric. Texts of this sort consequently offer the Marxist critic a paradox that has not always been appreciated. If we ask what organic historicism finds difficult to assimilate, one answer, according to "The Natural History of German Life," is indeed the proletariat-"the sign and result of the decomposition which is commencing in the organic constitution of society"

12. Philippe Lacoue-Labarthe and Jean-Luc Nancy, The Literary Absolute: The Theory of Literature in German Romanticism, trans. Philip Barnard and Cheryl Lester (Albany: State University of New York Press, 1988), 49. Hegel's phrase is cited in J. Hillis Miller, "Narrative and History," ELH 41 (1974): 455; Miller is quoting Nietzsche quoting Hegel, "Die Weltgeschichte," Enzyklopädie der philosophischen Wissenschaften im Grundrisse (1830), para. 549. 
(Pinney, 295). But a more general answer, with regard to the novels, would be the unhistoric field of the sentimental narrative itself. Terry Eagleton is certainly right to claim that Middlemarch, like many texts of its era and social provenance, casts "objective social relations into interpersonal terms," but it must be added that the latter thereby become the site of considerable tension. Rather than simply denounce the reduction of the historical to the intersubjective, we should consider the possibility that the intersubjective model might eventually, and in its own despite, find itself marked by a more genuine historicity than that offered either by the novel's periodizing detail or by its organic metaphors of historical development. ${ }^{13}$

The educative passage from narcissism to sympathy turns on a discontinuity, a gap between narcissistic illusion and the desire of the other; and this discontinuity manifests itself as a check or blow, which, as an intersubjective event, has a linguistic component. Not infrequently in Eliot's novels, blows are delivered verbally, their force sometimes figured in Gothic fashion as that of a brand or inscription: when Will Ladislaw lashes out at Rosamond, "what another nature felt in opposition to her own" is "burnt and bitten into her consciousness" (Middlemarch, 836). ${ }^{14}$ What Will has to say-that his desire is other, directed at an other-is bound up with what his words do: their violence is their message. And though this particular scene has a satisfying ethical and structural simplicity to it-Rosamond has misread the signs of Will's desire, and her punishment consists in an accession to truth - the image of language burning and biting conveys a hint of deeper complications and suggests a less stable economy of representations and pleasures. We might briefly consider here a famous moment in Daniel Deronda: when Gwendolen tells Daniel that she "saw [her] wish outside [her]" while watching her terrible husband Grandcourt drown, she conveys the intensity of an event suspended between realist convention and Gothic allegory as the externalization of a desire. ${ }^{15}$ The desiring self becomes the locus of uncertain agency (did Gwendolen's "murderous thought" have an "outward effect," causing her to hesitate to throw a rope?

13. Terry Eagleton, Criticism and Ideology: A Study in Marxist Literary Theory (London: Verso Press, 1978 [1976]), 121. See pp. 110-25 for a fine discussion of Eliot's ideological profile as a liberal urban intellectual; for a more recent and in-depth study, see Daniel Cottom, Social Figures: George Eliot, Social History, and Literary Representation (Minneapolis: University of Minnesota Press, 1987).

14. Neil Hertz comments on the "scenes of morally impeccable denunciation" that punctuate George Eliot's novels, "thoroughly gratifying scenes in which one character is licensed to verbally excoriate another" in "Some Words in George Eliot; Nullify, Neutral, Numb, Number," in Languages of the Unsayable: The Play of Negativity in Literature and Literary Theory, ed. Sanford Budick and Wolfgang Iser (New York: Columbia University Press, 1989), 28o. I discuss this essay and the issues it raises in greater detail below.

15. George Eliot, Daniel Deronda, ed. Barbara Hardy (Harmondsworth: Penguin, 1967), 761. Subsequent references are to this edition. 
[Daniel Deronda, 762]) and the text that has generated this self and its predicament thematizes itself as caught up in this uncertainty (is there a certain wishfulness at work in narratives in which characters such as Grandcourt or Casaubon come to grief, after serving as instruments of education or punishment?). The touch of sadism flavoring the image of Will's words burning and biting Rosamond's consciousness here becomes more systematically a part of the text's ethical texture. Meanwhile, the violence of sympathetic pedagogy spreads to the point that the pupil, Gwendolen, is educated only to the extent that she is ravaged by an event at once part of her and beyond her control, at once an occurrence and a recurrence-a symptomatic return of the "dead face" that has haunted her since the narrative began.

Such scenes, in other words, bring into focus the question of their own production. Reflecting on itself, the novel worries the status of its ethical categories even as it enforces them, and the question for the interpreter is whether or not the text's own ethical vocabulary can ultimately account for its operations. Critics have frequently noted the pressure of what F. R. Leavis disapprovingly calls "an emotional quality" that recurs in Eliot's prose, "something that strikes us as the direct (and sometimes embarrassing) presence of the author's own personal need."16 Because Eliot's texts thematize imaginative activity in terms of egoism and sympathy, a comment such as Leavis's reaches further than it might otherwise: in a George Eliot novel, as Neil Hertz observes, "the play between imaginer and imagined, between author and character, and the possibility of a narcissistic confusion developing between the one and the other, has already been thematized and made available for interpretations." 17 The problem of whose wish, if any, is being realized when Grandcourt drowns derives from the terms of Eliot's imaginative project. But if, on the one hand, sympathy can always be reascribed to narcissism, on the other hand, the omnipotence of narcissism is nothing if not the essence of narcissistic fantasy-the very fantasy that Eliot's pedagogical fictions so patiently expose.

The question raised by Grandcourt's death-how and why can a wish be (or promise, or threaten to be) an act?-is a version of the question of how and why words burn or bite a consciousness, or more generally, how linguistic acts can be said to have a referential power that also feels like violence. An uneasy link among sympathy, fiction, and force surfaces repeatedly in Eliot's novels, and may be understood as a response to the problematic of fictional identification: an author, one might say a little

16. F. R. Leavis, The Great Tradition (London: Chatto and Windus, 1948), 32.

17. Neil Hertz, "Recognizing Casaubon," in The End of the Line: Essays on Psychoanalysis and the Sublime (New York: Columbia University Press, 1985), 82. Further references are indicated by page number prefixed when necessary by the abbreviation $E L$. 
reductively, sees her wish outside her thanks to language's ability to refer to nothing at all, which means that the burden of authorial narcissism comes accompanied by the specter of the sign's irreducibility to self-presence. In Middlemarch, difficulties cluster around Dorothea's instrument of education, Mr. Casaubon, who, as Hertz has shown, is "made to seem not merely an especially sterile and egotistical person, but at moments like a quasiallegorical figure, the personification of the dead letter, the written word" $(E L, 78)$. His quest for the key to all mythologies has about it not just the mustiness of self-obsession, but the free play of an irresponsible fiction:

Doubtless a vigorous error vigorously pursued has kept the embryos of truth a-breathing. . . . But Mr Casaubon's theory of the elements was not likely to bruise itself unawares against discoveries: it floated among flexible conjectures no more solid than those etymologies which seemed strong because of likeness in sound, until it was shown that likeness of sound made them impossible: it was a method of interpretation which was not tested by the necessity of forming anything which had sharper collisions than an elaborate notion of Gog and Magog: it was as free from interruption as a plan for threading the stars together. (520)

Casaubon collects these attributes in part because they compose the precipitate of a novelist's-George Eliot's-identification with a characterDorothea-whose existence depends as much as Casaubon's on the "semicolons and parentheses" that, Mrs. Cadwallader jokes, circulate in Casaubon's body as a substitute for blood (Hertz, EL, 96). Similar symptoms of difficulty, as we shall see, plague the Lydgate half of the novel; but we may begin by examining Dorothea's aesthetic education, which forms the text's ethical centerpiece and negotiates both the possibility of a sympathetic aesthetic and that of aesthetic history.

I I

The strengths of the sentimental tradition, the tensions at play in it, and the power and subtlety of Eliot's aesthetic and ethical project manifest themselves with clarity in the extraordinary scene in Middlemarch in which Dorothea, newly married to Mr. Casaubon, seeks to shoulder "the weight of unintelligible Rome":

Ruins and basilicas, palaces and colossi, set in the midst of a sordid present, where all that was living and warm-blooded seemed sunk in the deep degeneracy of a superstition divorced from reverence; the dimmer and yet eager Titanic life gazing and struggling on walls and ceilings; the long 
vistas of white forms whose marble eyes seemed to hold the monotonous light of an alien world: all this vast wreck of ambitious ideals, sensuous and spiritual, mixed confusedly with the signs of breathing forgetfulness and degradation, at first jarred her with an electric shock, and then urged themselves upon her with that ache belonging to a glut of confused ideas which check the flow of emotion. Forms both pale and glowing took possession of her young sense, and fixed themselves in her memory even when she was not thinking of them, preparing strange associations which remained through her after-years. Our moods are apt to bring with them images which succeed each other like the magic-lantern pictures of a doze; and in certain states of dull forlornness Dorothea all her life continued to see the vastness of St Peter's, the huge bronze canopy, the excited intention in the attitudes and garments of the prophets and evangelists in the mosaics above, and the red drapery which was being hung for Christmas spreading itself everywhere like a disease of the retina. (225-26)

To come to terms with Rome is to come to terms with Casaubon, whose "equivalent centre of self" it will be Dorothea's task to recognize; and as Hertz comments, that ethical task may be taken as "quite literally, a domestication" $(E L, 92)$ of this overpowering encounter with the "city of visible history" (Middlemarch, 224). ${ }^{18}$ Two other moments of resolution suggest themselves, Hertz adds: the darkly sublime evocation of Dorothea's haunted consciousness that closes this paragraph ("in certain states of dull forlornness Dorothea all her life continued to see..."); and the muchquoted lines that close a subsequent paragraph: "If we had a keen vision and feeling of all ordinary human life, it would be like hearing the grass grow and the squirrel's heart beat, and we should die of that roar which lies on the other side of silence" (226). These three responses to the "weight of unintelligible Rome" negotiate the necessity and the limits of an act of identification that is at once sympathetic and fictional.

We may add to this observation that Dorothea's sympathetic education-her progress toward the recognition of Casaubon-unfolds as a specifically aesthetic education and displays its discomforts in this idiom. It has already been pointed out in general terms that organicism is an aestheticism and that the act of sympathy implicitly mobilizes the formalizing power of aesthetic judgment; but to appreciate fully Dorothea's itinerary through Rome we should recall that, like Casaubon, Dorothea serves the narrative as a symbol as well as a character, and that what she symbol-

18. Jacqueline Rose has called Gwendolen, in Daniel Deronda, the "original literary hysteric," and probably had this passage in mind when she added that "the reference to hysteria was already present, albeit in a muted form, in Dorothea Brooke." See "George Eliot and the Spectacle of the Woman," in her Sexuality in the Field of Vision (London: Verso, 1986), 116. Rose also points out that "Saint Theresa was the patron saint of hysteria" (114). 
izes is the insertion of symbolic value into realist narrative. Where Daniel Deronda begins with an aesthetic judgment aimed at a woman and turned into a question ("Was she beautiful or not beautiful?"), Middlemarch begins with the corresponding assertion ("Miss Brooke had that kind of beauty which seems to be thrown into relief by poor dress") and in fact draws attention to the particular aesthetic codes that Dorothea, a Puritan overwhelmed by Catholic Rome, will find exceptionally hard to understand ("Her hand and wrist were so finely formed that she could wear sleeves not less bare of style than those in which the Blessed Virgin appeared to Italian painters" [29]). Dorothea is the locus of aesthetic embodiment, and of the aesthetic irony with which this embodiment occurs. She will never entirely approve of the allegorical language of art that she nonetheless indirectly ratifies in specifically aesthetic fashion: that is, via the signs she provides of a potentially universal humanness. In no literal sense is she Saint Theresa or any of the numerous other saints that halo her presence in the novel; she is rather a figure for the eventual propriety of these figures. The balance is a delicate one, and the ironic nuances are worked out most clearly in their appropriate place-Naumann's studio in Rome, where the painter pretends to see Aquinas in Casaubon in order to paint Dorothea as Santa Clara. Casaubon is not "the idealistic in the real," and, crucially, neither is Dorothea. In aesthetic history the ideal is never entirely present; and when Naumann expatiates on Dorothea's beauty—to Will Ladislaw's irritation since "the ordinary phrases which might apply to mere bodily presences were not applicable to her" - the narrator provides the necessary parenthesis: "Certainly all Tipton," not to mention Dorothea herself, would have been surprised: "In that part of the world Miss Brooke had been only a 'fine young woman'" (250). The aesthetic can appear only as a promise of itself, and the Middlemarch narrator's wise and melancholy poise derives in part from the finely calibrated distance this narrative voice takes from affirmations that must also nonetheless be registered, and which are thus often routed through Will's proleptically Pateresque consciousness. ${ }^{19}$

19. "[T] he bow of a violin drawn near him cleverly, would at one stroke change the aspect of the world for him" (Middlemarch, 423). Will's commitment to what Mr. Casaubon describes as "the vague pursuit of what he calls culture" (106) is a little anachronistic in 1832, but plays an important role in the text's aesthetic system, not least because, as mentioned above, the narrator's irony can play off Will's aesthetic enthusiasm-as when he tells Dorothea "you are a poem" (256), finds her voice to resemble an "Aeolian harp" (105), and so on. Will Ladislaw is an interesting figure from the point of view of a study of aesthetics. Like Dorothea, he is a locus of aesthetic embodiment, with the emphasis cast more on the uncertain free play of aesthetic form: "a bright creature, abundant in uncertain promises" (512). He is linked through genealogy to the dead letter of Casaubon, on the one hand, and the sterile, hypercommodified world of Bulstrode, on the other; however, his grandmother had "not even a family likeness" to her sister, Casaubon's mother (101), and acts of disinheritance on both sides of the family frame him as aesthetic man. It is significant that, for all his associations with music, the stage, and a 
Dorothea, in short, exemplifies the affirmative structure of the novel's ethical and representational system, which in all of its manifestations depends on aesthetic irony. In this system, signs mislead, but they do so in order to return themselves to their proper meaning at the far side of history's error. Bodies, in Middlemarch, do not always correspond reliably to interior states, but they promise eventual legibility: if the organic body is to be the self's unconscious historicity, the body must finally be an aesthetic body. Similarly, Middlemarchian common sense may be too common to judge Dorothea, Rosamond, or Fred and Mary accurately, but it at least knows that Dorothea is "too unusual and striking," that Bulstrode is essentially untrustworthy, and so on: in aesthetic history, doxa must be wrong only within the potential of its own truth. And aesthetic irony demands, and receives in the person of Dorothea, a ratification of the signs of irony's eventual demise. It is thus inevitable that the shock and trauma of her sympathetic education should unfold as a confrontation with art, and with history as the history of art. In encountering Rome, Dorothea provokes the text into an intense negotiation of fictional identification precisely because in this scene the stability of the aesthetic is at stake.

Consequently, the threat that Casaubon represents and domesticates inheres in the aesthetic itself, and Dorothea's relation to art remains a troubled one. Pictures, she tells Casaubon, after he has introduced her to Will, "are a language I do not understand. I suppose there is some relation between pictures and nature which I am too ignorant to feel-just as you see what a Greek sentence stands for which means nothing to me" (105). Her aesthetic education, which as we have seen, parallels her sympathetic education and in a deeper sense comprises it, enjoys indifferent success. It is true that the "Italian painters" whose Madonnas she resembles become less "monstrous" after she begins to learn art's language in Naumann's studio: "[S]ome things which had seemed monstrous to her were gathering intelligibility and even a natural meaning" (246). ${ }^{20}$ But this ambivalent progress never takes her far from a specifically aesthetic trauma: "'At first when I enter a room where the walls are covered with frescoes or with rare

non-English bohemian levity, he will eventually go into politics: as aesthetic man he must finally be representative. Eliot's difficulty with this character is symptomatic of the tension Middlemarch puts on its own aesthetic.

20. And later in the text Dorothea will develop her ambivalence about art into a political critique: certain that much art is unsympathetic and cut off from the masses, she would prefer to "make life beautiful" — an activist stance that Will calls "the fanaticism of sympathy" (Middlemarch, 252). This theme climaxes in Dorothea's sharply political critique of the picturesque: after the completion of her aesthetic education (which includes the death of Casaubon), she comes to realize why she never liked the paintings in the well-traveled Mr. Brooke's collection: they sentimentalize real suffering and constitute "a wicked attempt to find delight in what is false" (424): a judgment the narrator echoes a little later when Brooke visits Freeman's End (429). 
pictures, I feel a kind of awe-like a child present at great ceremonies where there are grand robes and processions; I feel myself in the presence of some higher life than my own. But when I begin to examine the pictures one by one, the life goes out of them, or else is something violent and strange to me" (238). The "violent and strange" dimension of the aesthetic reappears in less central but more lurid fashion in the story of Lydgate's scientific education.

\section{I I}

Lydgate's doomed quest for the "primitive tissue" orients him toward the figurative essence of the novel, and thereby makes him into an ethically and rhetorically complex character. In both its metaphorical and literal dimensions his project ensures that he will fall victim to the narrator's irony, which here is equally the irony of history: "What was the primitive tissue? In that way Lydgate put the question - not quite in the way required by the awaiting answer, but such missing of the right word befalls many seekers" (178). He will eventually betray this quest by betraying his professional ideal. Yet, like Dorothea, he testifies to the value of ardent error, since in his very choice of profession he is participating — unhistorically-in its historical development. Like Wilhelm Meister, Lydgate believes that medicine synthesizes theory and practice, calling forth the "highest intellectual strain" yet keeping the researcher "in good warm contact" with other human beings. And the high intellectual strain of medical research bears a remarkable resemblance to the imaginative gift of the mimetic artist, as critics have frequently remarked:

Many men have been praised as vividly imaginative on the strength of their profuseness in indifferent drawing or cheap narration:-reports of very poor talk going on in distant orbs; or portraits of Lucifer coming down on his bad errands as a large ugly man with bat's wings and spurts of phosphorescence; or exaggerations of wantonness that seem to reflect life in a diseased dream. But these kinds of inspiration Lydgate regarded as rather vulgar and vinous compared with the imagination that reveals subtle actions inaccessible by any sort of lens, but tracked in that outer darkness through long pathways of necessary sequence by the inward light which is the last refinement of Energy, capable of bathing even the ethereal atoms in its ideally illuminated space. He . . wanted to pierce the obscurity of those minute processes which prepare human misery and joy, those invisible thoroughfares which are the first lurking-places of anguish, mania, and crime, that delicate poise and transition which determine the growth of happy or unhappy consciousness. (194) 
Particularly in its concluding sentence, this passage would seem to be describing the panoptic procedures of the novelist even more than those of the social scientist; and it has proved easy to discern in Lydgate's valorization of the scientific imagination "George Eliot's reflection on her own assumptions and beliefs." 21 Less frequently noted is the curious passion with which this passage invokes and discards a different kind of imagination, as though the "inward light" of the scientific mind instantly cast Gothic shadows, as it might in Frankenstein or Faust.

If Lydgate is an authorial surrogate, he is also persistently the locus of suspect sorts of literariness. It is he, not Casaubon, who is termed "a cluster of signs for his neighbors' false suppositions" (Middlemarch, 171); and while the suppositions may be legibly false, as when Mrs Dollop-her eye, perhaps, on Wilhelm Meisters Wanderjahre - suspects him of murder and graverobbing, even this lurid bit of doxa acquires resonance when Lydgate finds it necessary to tell an unappreciative Rosamond of his admiration for the grave-robbing Vesalius (497). The origin of his "intellectual passion" has a Gothic feel to it, and entails an act of reading: on a rainy day the young Lydgate opens a volume of "an old Cyclopaedia" at random, and stumbles on a description of the valves of the heart: "He was not much acquainted with valves of any sort, but he knew that valvae were folding doors, and through this crevice came a sudden light startling him with his first vivid notion of finely adjusted mechanism in the human frame" (173). Not only does his career-his symbolically resonant search for the "primitive tissue" - unfold from the chance event of a signifier, but the "light" shining through its "crevice" has been made possible by a "liberal education," which (besides leaving him "free to read the indecent passages in the school classics") has enabled him to read valvae in valves, thus producing the "crevice" for the imagination's light. Everywhere in Lydgate's story one seems to encounter literature. He bears a poet's name; his "intellectual passion" resembles the love "sung by the Troubadours" (173); and "the primitive tissue" remains "his fair unknown" (305) until a more literal sort of love life generates too many obstacles.

It is in his erotic entanglements that Lydgate's literary ones become most visible, since his "spots of commonness" manifest themselves most strikingly in his relegation of women to the domain of cultured leisure. His

21. Shuttleworth, George Eliot and Nineteenth-Century Science, 143. Nearly all treatments of "Middlemarch and science" take Lydgate as representative of George Eliot's own imaginative procedures and ideals. One is reminded of Zola's "il me suffira de remplacer le mot 'medecin' par le mot 'romancier'." Le roman experimental, in Oeuvres Completes (Paris: Bernouard, 1928), 41:11. The stress under which critics labor when they cast Eliot as a scientist is legible in the degree to which their formulations frequently work to efface the fictional altogether: e.g., "Middlemarch is a work of experimental science" (Shuttleworth, George Eliot and NineteenthCentury Science, 143). 
encounter with Madame Laure, which İ shall consider at greater length in a moment, allows melodrama to erupt into his plot; and his courtship and marriage to Rosamond Vincy links his fate to that of a character described by Mary Garth as "just the sort of beautiful creature that is imprisoned with ogres in fairy tales" (166). Rosamond also functions as the locus of more systematic high literary allusion. Her bourgeois origins, romanceconditioned imagination, expensive habits, and marital dominance align her with the wife of another literary doctor; when the text has Rosamond and Lydgate's interest in each other begin when Lydgate gallantly hands her the whip for which she is reaching (144-45), the reference to Madame Bovary has all the signs of being purposeful.22 In the course of time Rosamond will experiment in timid Victorian fashion with an Emma Bovary career: Captain Lydgate and Will are lightly sounded echos of Rodolphe and Léon. In meeting and marrying Rosamond, Lydgate has not just walked into a literary plot, but into the plot of a novel about the incessant and damaging novelization of life.

Consequently, in Lydgate's orbit the border between life and art, high and low literature, realism and romance, romance and melodrama, is strikingly permeable: "'Would she kill me because I wearied her?' " he wonders late in the novel (638), thinking of Rosamond but alluding of course to Laure, the actress who kills her husband by mistake on purpose during the performance of a Parisian melodrama, and who in turn serves as the cynosure of a variety of literary codes. Madame Laure earns her living by acting in plays that presumably "reflect life in a diseased dream," but she comes curiously adorned with tokens of high culture: she is a "Provençale," with a Petrarchan name and "dark eyes, a Greek profile, and rounded majestic form" (180). In certain respects Lydgate's encounter with her complements Dorothea's encounter with Rome: both scenes take place at an extreme remove from the middle-march of life in Middlemarch; both occasion self-conscious reflections on narrative procedure ("For those who want to be acquainted with Lydgate it will be good to know what was that case of impetuous folly. . . . The story can be told without many words"); and both appear to respond to non-dramatic necessities. The story of Madame Laure has elicited critical attention in recent years, but its oddity is still frequently underappreciated. ${ }^{23}$ It is a story of mimetic contagion. After

22. Gustave Flaubert, Madame Bovary: Moeurs de province, 1.2: Charles, on his first visit to the Rouault home, is looking for his whip: "It had fallen to the ground, between the sacks and the wall. Mademoiselle Emma saw it, and bent over the flour sacks. Charles out of politeness made a dash also, and as he stretched out his arm, at the same moment felt his breast brush against the back of the young girl bending beneath him. She drew herself up, scarlet, and looked at him over her shoulder as she handed him his riding crop." Madame Bovary, ed. and trans. Paul de Man (New York: Norton, 1965), 12.

23. It is becoming a well-trodden topos, however. In addition to Simon During's essay cited in 
Laure translates art into reality, really stabbing her husband instead of acting the mistaken stabbing of her lover disguised as the evil duke (and played by her real-life husband), Lydgate "really" falls in love with her and seeks her out in Avignon, causing even Laure to wonder at the infectiousness of melodrama: "You have come all the way from Paris to find me? . . . Are all Englishmen like that?" Their subsequent conversation is arguably the most bizarre in mainstream Victorian fiction. "My foot really slipped," Laure tells Lydgate. However, she continues, "I meant to do it." Lydgate appeals to the possibility of complex hermeneutic and emotional depths: "There was a secret, then," he suggests. "You hated him." But Laure is Eliot's one truly existential killer: "No! he wearied me; he was too fond: he would live in Paris, and not in my country, and that was not agreeable to me." Finally she rules out premeditation: "I did not plan: it came to me in the play-I meant to do it" (182).

As Simon During has shown, this curious scene possibly alludes to a famous murder case in Paris in $1825 . .^{24}$ More immediately, as feminist criticism from Gilbert and Gubar onward has noted, the episode gives melodramatic expression to the violence glinting in the turns of the realist text,

the subsequent note, see David Ferris's subtle and extensive discussions of the Laure episode in Theory and the Evasion of History (Baltimore: Johns Hopkins University Press, 1993); unfortunately I discovered this book too late to do more than signal the congruity I perceive between Ferris's approach and my own. Feminist criticism since the 1970s has drawn attention to Middlemarch's Laure episode, often citing it as a particularly violent version of a connection between murder and marriage that Eliot's texts frequently make. See especially Sandra M. Gilbert and Susan Gubar, The Madwoman in the Attic: The Woman Writer and the NineteenthCentury Literary Imagination (New Haven: Yale University Press, 1979), 499-520; Nina Auerbach, Romantic Imprisonment: Women and Other Glorified Outcasts (New York: Columbia University Press, 1986), 253-67; and Jacqueline Rose, "George Eliot and the Spectacle of the Woman."

24. Simon During, "The Strange Case of Monomania: Patriarchy in Literature, Murder in Middlemarch, Drowning in Daniel Deronda," Representations 23 (1988): 86-104. The murder inspired the production of a short-lived medical category called "monomania" in order to account for the perpetrator's apparent absence of motive. Monomania, During explains, "indicated a localized but profound break in the unity of the psyche. . . At the most abstract level it operated on the classical divisions between the faculties: in monomania, will separated from emotion, reason from will, emotion from reason." Its peculiarity lay in its being a "pathology of structure rather than of content, so that the faculties themselves remained in order" (86). With the disappearance of faculty-psychology in the middle of the century, this classification was forgotten or ignored.

The term "monomania" seems to have circulated well beyond the medical and juridical contexts that During invokes, however. It appears in Edgar Allan Poe's short story "Berenice" (1835) to describe the narrator's "morbid attention" to objects that are "invariably frivolous," and at one point characterizes his habit of repeating "monotonously some common word, until the sound, by dint of frequent repetition, ceased to convey any idea whatever to the mind." The Complete Edgar Allan Poe Tales (London: Guild, 1984), 10. In the course of the story, the monomaniacal gaze fixes on Berenice's teeth: "Then came the full fury of my monomania," here taking the form of believing that these arbitrary signifiers are at once "ideas" and apotropaic fetishes ("I felt that their possession could alone ever restore us to peace, in giving me back to reason" [12]). 
particularly when the story is of husbands and wives. When Dorothea, in her scene with Rosamond late in the novel, says that misdirected love "murders our marriage-and then the marriage stays with us like a murder" (855), the metaphor resonates in a web we have already sketched: Casaubon's death, like Grandcourt's in Daniel Deronda's far more charged reworking of this topos, arrives with the convenience of a fiction, and leaves a residue that Eliot's texts represent in the figure of ambiguous murder. Murder is a crime of omission in George Eliot novels: if killing may be taken as action in its purest manifestation as violence, Eliot's texts worry the status of the act as a play of conflicting motives and circumstancesand not only when the death of a husband is in question: Bulstrode's murder of Raffles provides an elegant instance of such ethical discrimination. ${ }^{25}$ But Casaubon's and Grandcourt's deaths provoke the supplemental and less stable question of what it means for an "author" to "act" - that is, in this idiom, to kill a fictional character, or identify with one, thereby seeing her wish outside her: murder, in other words, becomes the site for the staging of the question of what the act of fiction (as sympathy) is.

And with Madame Laure's murderous blow, agency becomes irreducible to intention or desire, let alone egoism. According to Laure, her blow, which annihilates the difference between representation and reality (or fictional character and "author"), is at once the expression of a pure intention ("I meant to do it"), a citation or quote ("It came to me in the play"), and an accident ("My foot really slipped"). Meaning (as the sheer form of intentionality) mimes perfectly an occurrence (the blow), but the articulation between these two dimensions loses its certainty: her blow is an intended accident and an accidental intention. Intention, here indistinguishable from a slip of the foot, can no longer guarantee a difference between its own pure occasion and the randomness of an event, and furthermore discovers its predicament only as a citation, as the mechanical reiteration of a text produced by "collaborating authors" (180). ${ }^{26}$

25. Particularly since Bulstrode's actions acquire their meaning from their context: the liquor he allows the housekeeper Mrs. Abel to give to Raffles was proscribed by Lydgate but would have been prescribed by the older medical school of Toller and Wrench (Middlemarch, 774). The complexity of the murderous act is discoverable even in violent scenes such as that in which Baldassare kills Tito in Romola. Tito appears already dead when Baldassare finds him; Baldassare kneels beside the body "watching the face," and when Tito's eyes open he begins strangling him: "Tito knew him; but he did not know whether it was life or death that had brought him into the presence of his injured father." Romola, ed. Andrew Sanders (Harmondsworth: Penguin, 1980), 638.

26. Simon During's interesting reading of this scene through the lens of "monomania" oversimplifies the conundrum of Laure's blow: "Without monomania two alternative readings are possible: either Laure is a liar who really did accidentally slip and is now frightening her persistent suitor off, or she is a criminal safely confessing at last. Monomania destroys this 
Thus struck, Lydgate retreats into the error diagnosed in Middlemarch's "Prelude": he resolves that henceforth he will "take a strictly scientific view of women" (183), and thereby consigns himself to a blind repetition of literary emplotment. For the "scientific" view of women is inseparable from their aestheticization - their relegation to what Middlemarch's "Prelude" called "indefiniteness" (26). The Laure episode demonstrates what the rest of Lydgate's plot confirms: that the "intellectual passion" of the male scientific enterprise is permeable to, and possibly another version of, the "preconceived romance" into which Rosamond processes experience (195). Thus the novel that generates and weighs these categories and destinies has also told the story of the literariness of its own aestheticizing scientificity. The threat Dorothea is represented as perceiving in art inheres in the "primitive tissue" of the text that valorizes her. For Laure's blow constitutes the ultimately "unhistoric," domestic, female act, yet deprives the body of its reservoir of meaning and makes it the site of uncertain accident, an element in an undecidable textual process. Her blow performs the contagion of bad, anonymous art, the (non-)art of the crowd, and in this sense may be understood as a political blow precisely to the extent that it is uncertainly and uncontrollably literary. The blow's violence lies in its passage from figurative to literal status: it is precisely this slippage that is undecidably random or intentional. Yet the blow takes its origin in the domain of the figurative ("It came to me in the play"). Bad art, then, is a figure that does not know whether it is figurative or literal and cannot control the difference: hence the contagiousness of melodrama. The physician is at the center of this epidemic, aggravating it by trying to isolate and cure it. And Eliot's text, repeating the physician's predicament, quarantines this rhetorical plague within the ethical and aesthetic categories of melodrama and narcissism only at the cost of exposing organic history to

division by turning her wish for autonomy into a fiction that can make illusory sense of her motiveless act" ("The Strange Case of Monomania," 93). This way of stating the problem imposes alternatives that the text disallows: the scene holds interest precisely because a slip (of the body) and an intent (of the mind) become at once radically different and radically indistinguishable within the context of a mechanically reiterated text (the melodrama). During's analysis is in part set up to prepare a rebuttal of Paul de Man's reading of Rousseau's Confessions in Allegories of Reading (New Haven: Yale University Press, 1979). The difficulty of de Man's text prevents me from entering into that particular debate here; it will have to suffice to note that During needs to underplay the paradoxes of Laure's blow so as to allow a firmly historical category - "monomania" - to frame and explain the text. A fine reading of de Man's subtle and violent reading of Rousseau may be found in Ortwin de Graef, "Silence to Be Observed: A Trial for Paul de Man's Inexcusable Confessions," Postmodern Studies 2: (Dis)continuities: Essays on Paul de Man, ed. Luc Herman et al. (Amsterdam/Antwerp: Rodopi/ Restant, 1989), 51-73. 
disease, and raising the suspicion that a certain illegible, literary contagion infects and enables sympathy.

\section{V}

The further pursuit of these questions will take us past Middlemarch's borders. We have seen that pockets of stress inhabit both the Dorothea and the Lydgate plots, yet Middlemarch's aesthetic of sympathy remains relatively stable because the text leaves relatively unquestioned the homology between the sympathetic and the ardent. Characters such as Casaubon and Madame Laure are judged and exiled in vitalistic terms: they are morally deficient at least in part because they lack energy. They personify the error of the ardent soul; however, in the sheer generosity of its error the sympathetic soul remains a locus of value. Eliot's subsequent writing was to be more acutely haunted by the specter at work within the sympathetic aesthetic; and despite the bulk and complexity of Daniel Deronda, we may briefly consider here a set of passages to which Neil Hertz has drawn attention, in which this novel's themes of gambling and theatrical performance bring the sympathetic imagination into proximity with a certain mechanical, iterative passivity. Though the summary comments I offer over the next few pages make a poor substitute for Hertz's patient reading of Deronda, they will prepare us to trace continuities between Middlemarch's organic fiction and a Gothic theme of telepathy which, as I hope to show in the final section of this chapter, haunts the extremities of George Eliot's oeuvre.

It is only a slight exaggeration to say that Madame Laure returns in Eliot's oeuvre as Daniel Deronda's mother, who is herself a minimally displaced representation of Daniel Deronda's author. A world-famous, aging actress, the Princess Halm-Eberstein appears late in the novel in answer to Daniel's desire; and this "wish" that he, like Gwendolen, finally sees "outside him" poses a threatening resistance to his sympathy. The Princess is the last in a long series of female characters in Eliot's fiction whose egoism has murderous potential. When Daniel was two years old, the Princess had offered him to an old friend for adoption so as to pursue her career; during his interview with his mother Daniel melodramatically charges her with having "willed to annihilate" his identity as a Jew (Daniel Deronda, 727). ${ }^{27}$ But the threat the Princess poses to the sympathetic imagination cannot be entirely translated into a dramatic and ethical vocabulary. The most ex-

27. His grandfather, he now learns, had been a "physician": a curious detail that reinforces the link between the Princess and Laure-though certainly Daniel's almost mythically patriarchal grandfather is in all other respects no Lydgate: "A man to be admired in a play_-grand, with an iron will" (Daniel Deronda, 694). 
traordinary passages in this somberly passionate scene are those in which Eliot seeks to render the Princess's consciousness:

[T] his woman's nature was one in which all feeling-and all the more when it was tragic as well as real-immediately became matter of conscious representation: experience immediately passed into drama, and she acted her own emotions. In a minor degree this is nothing uncommon, but in the Princess the acting had a rare perfection of physiognomy, voice, and gesture. It would not be true to say that she felt less because of this double consciousness: she felt-that is, her mind went through —all the more, but with a difference: each nucleus of pain or pleasure had a deep atmosphere of the excitement or spiritual intoxication which at once exalts and deadens. But Deronda made no reflection of this kind. (691-92)

The sharp exclusion of Daniel from the common ground of the narrator's and the Princess's consciousness returns the novel to its dramatic register but also signals the extent to which the text has deviated from that register in seeking language for the Princess's interiority. The differences constitutive of consciousness-between feeling and its representation, emotion and acted emotion-are first elaborated into the comparative abstraction of a "double consciousness," and then "further dispersed," as Hertz comments, "into an indefinite number of nuclei, atoms of experience characterized in the abstract idiom of their most common denominators as units of pain or pleasure, each surrounded by its own ambivalently exalting and deadening aura" ("Some Words," 295). The Princess is Eliot's most resonant and ambitious self-portrait: a mimetic artist with the talent, the energy, and the hubris to "care for the wide world, and all that I could represent in it" (Daniel Deronda, 693), and with the authority to rebuke Daniel's imperial sympathy: "No. . . You are not a woman. You may try—but you can never imagine what it is to have a man's force of genius in you, and yet to suffer the slavery of being a girl" (694).

The mother's appearance and (rapid) disappearance in this novel, as Hertz has shown, may be understood as a double gesture of affirmation and sacrifice: as George Eliot's "brief but intense experiment in writing herself into her text" $(E L, 224)$, but also as a means of focusing and controlling the kinds of difficulties that we have been examining throughout this chapter. By embodying a certain linguistic opacity, the Princess, like Casaubon, and to a certain extent like Madame Laure, allows that opacity to be translated into an ethical idiom, and symbolically expelled from the novel. But the representational questions she raises haunt the narrative in other ways, and they cluster particularly thickly around a character who, like the Princess, appears briefly and exits under an ethical cloud: Lapidoth, 
the "undesirable father" of Mordecai-Ezra and Mirah (Daniel Deronda, 849). Undesirable on numerous counts-he is a "shabby, foreign-looking, eager, and gesticulating man," and a habitual gambler (807) - Lapidoth will be upbraided both by the narrator and by Mordecai: "That is," Hertz comments dryly, "the arrival of the father is the occasion for one more of those scenes of morally impeccable denunciation that have punctuated George Eliot's fiction from the first" ("Some Words," 280). Like Will lashing out at Rosamond, Mordecai-Ezra denounces Lapidoth with a force that leaves the son "exhausted by the shock of his own irrepressible utterance" and makes the father "cry like a woman":

-and yet, strangely, while this hysterical crying was an inevitable reaction in [Lapidoth] under the stress of his son's words, it was also a conscious resource in a difficulty; just as in early life, when he was a brightfaced curly young man, he had been used to avail himself of this subtlypoised physical susceptibility to turn the edge of resentment or disapprobation. (Daniel Deronda, 847-48)

Lapidoth, like the Princess, "acts his own emotions," though not with the dignity of a great tragedian. His "hysterical" fit of crying is amenable to pragmatic exploitation, but as an occurrence, it is not under his control: the infection of life by art that the Princess embodies has now modulated into a grafting of intentionality, of "conscious resource," onto a "subtly-poised physical susceptibility." And the "poise" of Lapidoth's physical susceptibility is linked to the "poise" marking the consciousness of a gambler: "the habitual suspensive poise of the mind in actual or imaginary play" (843).

These passages prepare a final description of Lapidoth's consciousness, as he lies awake at night after his scene with Mordecai-Ezra, going "back over old Continental hours at Roulette, reproducing the method of his play, and the chances that had frustrated it":

These were the stronger visions of the night with Lapidoth, and not the worn frame of his ireful son uttering a terrible judgment. Ezra did pass across the gaming-table, and his words were audible; but he passed like an insubstantial ghost, and his words had the heart eaten out of them by numbers and movements that seemed to make the very tissue of Lapidoth's consciousness. (849)

"If that last sentence is surprising," Hertz comments, "it may be because it seems to be composed of better language than Lapidoth is quite entitled to." The abstract, enigmatic metaphor of a "tissue" composed of "numbers and movements" that "eat out the heart" of morally significant words has the density, even the dignity of a figure that resists easy visualization: "[I]t 
is as if paper were both receiving and corroding print, or as if a ground could both accept and invalidate a figure" ("Some Words," 283). Like the Princess, Lapidoth marks a limit to the efficacity of the sympathetic imagination, and does so in ways that draw attention to a threat at once internal to sympathy itself and linked to Daniel Deronda's running theme of gambling.

The "habitual suspensive poise" of the gambler, his compulsively repetitive representations of play, and the "numbers and movements" of his consciousness, recall other forms of mechanical behavior or states of mind in Daniel Deronda, such as Gwendolen's liability to hysteria, or Daniel's and Grandcourt's liability to different kinds of suspensive poise. Daniel's sympathy is so diffuse as to be paralyzing: his is a "reflectiveness that threatened to nullify all differences" (414). Grandcourt, Daniel's sinister double in many ways, but particularly in the matter of double consciousness, is frequently beset by a "languor of intention . . . like a fit of diseased numbness" (187): his will to thwart the expectations of others is so refined that it has trouble determining its object. The overlap between the "numbers" playing in the gambler's consciousness and the "numbness" afflicting sympathy on the one hand and a will to power on the other, occurs, Hertz suggests, "where motive is dispersed in equivocations, where agency is hard to distinguish from passivity, or from a poise that is at once suspensive and habitual" ("Some Words," 293). The mechanical, passive activity of the gambler summons these instances of ambiguous agency into a figure that to a certain extent allows for the reestablishment of ethical and thematic control.

But the body can no longer play the governing role it did in Eliot's earlier novel, and not simply because aesthetic power now explicitly involves mechanical prowess, as Klesmer tells Gwendolen: "Your muscles, your whole frame-must go like a watch, true, true, true, to a hair" (Daniel Deronda, 300). The body, framed as the body of sympathy, is also always a gambling body, and can no longer easily sacrifice itself to the construction of the organic historicity of a greater consciousness. Aesthetic embodiment has become a question ("Was she beautiful or not beautiful?"), asked by a male gaze of a female body ("She who raised these questions in Daniel Deronda's mind was gambling"): a body lodged in the inorganic architecture of a modern, historical, wearily literary consciousness ("not in the open air under a southern sky, tossing coppers on a ruined wall, with rags about her limbs, but in one of those splendid resorts which the enlightenment of ages has prepared for the same species of pleasure"). Jacqueline Rose rightly comments that in this novel "it is the degeneracy of the whole social body that is now in need of repair," and that Daniel's Zionist project rewrites in grand aesthetic-historical fashion Lydgate's search for the prim- 
itive tissue (Rose, Sexuality, 111). Yet in negotiating limits to its loss, Daniel Deronda not only splits into the two halves for which it is famous; it also offers up for sacrifice Middlemarch's most privileged organic image, and constructs the figure of a "tissue" made of numbers and movements that devour words.

V

In an intriguing displacement of a phrase by Jacques Derrida, Nicholas Royle remarks that it is "difficult to imagine a theory of fiction, a theory of the novel, without a theory of telepathy." 28 The claim may seem melodramatic, but it is a peculiarly apt formulation of the predicament of a sentimental aesthetic, particularly in its nineteenth-century narrative manifestations. The formal developments that culminated in Eliot's omniscient narrators and James's crafted perspectives cast narrative conventions as paradoxes of consciousness. A narrator becomes the locus of a knowledge at once excessive and insufficient, since the telling of a story depends both on the knowledge of its end and the suppression or forgetting of this knowledge. This is also to say that the narrator knows and does not know the characters whose consciousnesses, in composing the story, compose the narrative consciousness of the story. These paradoxes emerge from the sentimental and Gothic tradition as the formal complement to this tradition's interest in the subject of desire. The Gothic, with its premonitory and oversignificant ambience, its doublings and redoublings of characters and desires, might be called the genre of telepathy; the genre's overt preoccupation with the occult would in this sense be the symptom of a more general interest in a more diffuse haunting.

Like the Brontës and other writers in the nineteenth-century high Gothic tradition, George Eliot allowed mind-reading and clairvoyance to take overtly supernatural form in her fiction, though in Eliot's case this occurred only once and under resolutely particular circumstances. The Lifted Veil, a short story she interrupted work on The Mill on the Floss to write, is in certain respects heavily framed as a jeu de mélancolie to be kept at a distance from the serious, ethical work of literary realism. ${ }^{29}$ Yet the story is also

28. Nicholas Royle, Telepathy and Literature: Essays on the Reading Mind (London: Blackwell, 1990), 17. Cf. Jacques Derrida, "Telepathy," trans. Nicholas Royle, Oxford Literary Review 10 (1988): 3-41: "Difficult to imagine a theory of what they still call the unconscious without a theory of telepathy" (14): a phrase I discuss below.

29. "Jeu de mélancolie" is Eliot's phrase in a letter to Blackwood accompanying the manuscript; fourteen years after its publication she wrote to him to say that "[t]here are many things . . [in The Lifted Veil] which I would willingly say over again, and I shall never put in any other form." 
centered on the problematic of sympathy, and it has been widely recognized in recent years as a text that self-consciously "investigates and challenges two of [Eliot's] dearest values: sympathy and memory as the bases of moral action." 30 The telepathic, clairvoyant, first-person narrator, Latimer, presses the sympathetic imagination to its caricatural absolute before Eliot's fictional oeuvre is more than partly underway. He hears the "roar on the other side of silence" — for his power is "like a preternaturally heightened sense of hearing, making audible to one a roar of sound where others find perfect stillness" - and if he does not die of it, he admits into his consciousness a literary element that disturbs the difference between life and death, and disrupts the coherence of narcissism as an ethical category. ${ }^{31}$

For though Latimer is possessed of something like the "proud narrow sensitiveness" of a Mr. Casaubon, his assumption of the powers and burdens of an Eliotic narrator requires him to tell the story not just of his own life, but of his own death. As part of the text's self-conscious manipulation of narrative conventions and forms-one thinks of Moll Flanders' remark somewhat earlier in the history of the English novel that "no Body can write their own Life to the full End of it unless they can write it after they are dead"32_-death becomes The Lifted Veil's most prominent and complex narrative event. "The time of my end approaches," Latimer tells us in the text's opening sentence: "Just a month from this day, on the 2oth of September 1850, I shall be sitting in this chair, in this study, at ten o' clock at night, longing to die, weary of incessant insight and foresight, without delusions and without hope." There follows a proleptic representation of the experience of death itself:

The George Eliot Letters, ed. G. S. Haight (New Haven: Yale University Press, 1954-56), 3:41, 5:380.

30. Charles Swann, “Déjà Vu, Déjà Lu: 'The Lifted Veil' as an Experiment in Art," Literature and History 5.1 (1979): 42. Until relatively recently The Lifted Veil was rarely discussed in Eliot scholarship, but since the mid-seventies it has elicited many finecritical readings: in addition to Swann, see Sandra Gilbert and Susan Gubar, The Madwoman in the Attic, 443-77; Gillian Beer, "Myth and the Single Consciousness: Middlemarch and The Lifted Veil," in This Particular Web: Essays on Middlemarch, ed. Ian Adam (Toronto: University of Toronto Press, 1975), 91-115; Terry Eagleton, "Power and Knowledge in 'The Lifted Veil,'" Literature and History 9.1 (1983): 52-61. 31. George Eliot, The Lifted Veil (Harmondsworth: Penguin, 1985), 26. Subsequent references are to this edition.

32. Daniel Defoe, Moll Flanders, ed. David Blewett (Harmondsworth: Penguin, 1989), 42. The temporality of Latimer's consciousness is far more complex than can be indicated here. At times, like the damned in Dante's Inferno, he will know the past and the future but not the present; he can foresee his death but not the death of his desire for the blond femme fatale of the story, Bertha, or her desire for his death. His powers disappear at a certain point and are displaced onto a bizarre scientific fantasy, as a character who knows Bertha's desire for Latimer's death is given a blood transfusion, brought back from death and enabled, like Poe's Mr. Valdemar - and of course like Latimer himself - to speak from beyond the grave. For a fine analysis of the text's narrative and rhetorical complications, see Swann, "Déjà Vu, Déjà Lu." 
Darkness-darkness-no pain-nothing but darkness: but I am passing on and on through the darkness: my thought stays in the darkness, but always with a sense of moving onward....

Before that time comes, I wish to use my last hours of ease and strength in telling the strange story of my experience. (2)

The experience of death reveals itself here as exemplary of the category of experience per se, representing the plenitude of reality that narrative form will betray: both the plenitude and the betrayal register in the ellipsis points qualifying "onward." Yet if death is the exemplary experience, in its excess of content over form or reality over representation, it is also of course the exemplary non-experience, available only as form, representation, or language. Death cannot be represented, and can only be represented. The Lifted Veil situates Latimer's consciousness at the intersection of this paradox. Since he is clairvoyant, no event in his narrative can be located definitively in space or time: the character Latimer can become the narrating Latimer at any point, since the story of his life-which is to say his death-can unroll for him without his having "experienced" it. Precisely as a narrator, he is neither dead nor alive. The "2oth of September 1850" is undecidably past, present, and future at any "moment" or "point" in Latimer's narrative, as the story's closing sentences and final ellipsis points emphasize:

It is the 2oth of September 1850. I know these figures I have just written, as if they were a long familiar inscription. I have seen them on this page in my desk unnumbered times, when the scene of my dying struggle has opened upon me. . . (66-67)

Latimer's death, the exemplary (non)event, has already occurred and has not yet occurred, which is to say that it has occurred as an inscription which opens the possibility of death and life, but remains irreducible to either. Telepathy in this sense is a "metaphor for reading" (Royle, Telepathy and Literature, 96), and is a particularly appropriate metaphor for an aesthetic of sympathy, grounded in a predicament of reading it must disavow. The numbness and numbers that devour sympathy in Daniel Deronda may be thought of as the pressure of telepathy as an irreducible difference and distance (tele) within pathos; and, as Latimer's predicament emphasizes, this difference and distance is that of language in its materiality, in its dependence on "arbitrary marks," in Hertz's phrase, "without which no investments of any sort-not just no bets-would be conceivable" ("Some Words," 295).

Only clairvoyantly would Latimer have called himself a telepath, since the first recorded use of the word "telepathy" dates from two years after 
George Eliot's death. ${ }^{33}$ We have said enough to suggest the term's eccentric but fundamental position within an Enlightenment discourse of sympathy; it should be added that this term and its cognates emerge at the fault line between the late nineteenth-century popularization of the occult, on the one hand, and the new psychological and social sciences, on the other. Much like the various theories and practices of hypnosis or suggestion current at the time, and in certain respects like those of hysteria, telepathy takes its place in the history of the production of the human sciences as another version of what one of the fathers of sociology, Gabriel Tarde, called the "contagion" of "imitation." 34 From our present perspective this is not without interest. The self-dispersion toward which the tropes of writing, theatricality, and gambling gesture in Eliot's novels may also be represented in the terms of the question Mikkel Borch-Jacobsen hears in Freud's texts: "Does primary sociality begin in the stage of transition toward the object, of the face-to-face encounter with others? Or does it precede the positioning of others, which means the positioning of the ego as well?" 35 Borch-Jacobsen's focus is on Freud's writings on mass psychology, but in the process he comments on the widespread interest in telepathy among turn-of-the-century scholars, from Bergson and William James to the sociologists and crowd-theorists whose texts had direct influence on Freud's. Tarde, for instance, defines "pure and absolute" sociality as "such an intense concentration of urban life that as soon as a good idea arose in one mind it would be instantaneously transmitted to all minds throughout the city" (The Laws of Imitation, 70). One finds a similar sense of primary, even magical, sociality in Le Bon's theory of crowds. For Le Bon, in BorchJacobsen's summary, the "unconscious . . . is indissolubly nonsubjectal and 'social'," since Le Bon "never designates anything but immediate communication with others ... prior to any consciousness of self, and thus also prior to any consciousness of others. Taken to the extreme, it is thought transmission, telepathy...."36 As another name for the "contagion of

33. The OED lists "telepathy" as a coinage ventured in 1882 to "cover all cases of impression received at a distance without the normal operation of the recognized sense organs." See Frederick Myers et al., "First Report of the Literary Committee," Proceedings of the Society for Psychical Research, vol. 1, part 2 (London: Trübner, 1883), 147; cited in Royle, Telepathy and Literature, 2.

34. Gabriel Tarde, The Laws of Imitation, trans. Elsie Clews Parsons (New York: Henry Holt, 1903 [1895]), 11. Tarde's commitment to the principle of mimesis is so thoroughgoing that not only does society, in his text, begin "on the day when one man first copied another," but imitation itself turns out to be self-imitation, represented in psychological terms: "[E]very act of perception, in as much as it involves an act of memory, which it always does, implies a kind of habit, an unconscious imitation of self by self" (75).

35. Mikkel Borch-Jacobsen, The Freudian Subject, trans. Catherine Porter (Stanford: Stanford University Press, 1988), 133.

36. Borch-Jacobsen, The Freudian Subject, 140. From the viewpoint of a critique of aesthetic ideology as we elaborated it in chapter one, Le Bon's text and Borch-Jacobsen's discussion of it 
imitation" - a phrase that Le Bon uses in imitation of Tarde-telepathy figures repeatedly in writings of this period as a fantastic shadow cast by the production of theories and practices of psychology and sociology, technologies of propaganda and marketing, and the various sciences of the self and its unconscious.

Freud's own conceptualization of the unconscious has a relation to telepathy sufficiently intimate that on at least one occasion he proposed the unconscious as the mediating element which might ultimately grant telepathy an organic base-though the first analogy that comes to Freud's mind, significantly enough, is that of a technical apparatus, the telephone:

The analogy with other transformations, such as occur in speaking and hearing by telephone, would then be unmistakable. And only think if one could get hold of this physical equivalent of the psychical act! It would seem to me that psychoanalysis, by inserting the unconscious between what is physical and what was previously called "psychical," has paved the way for the assumption of such processes as telepathy. If only one accustoms oneself to the idea of telepathy, one can accomplish a great deal with it-for the time being, it is true, only in imagination. It is a familiar fact that we do not know how the common purpose comes about in the great insect communities: possibly it is done by means of a direct psychical transference of this kind. One is led to the suspicion that this is the original, archaic method of communication between individuals and that in the course of phylogenetic evolution it has been replaced by the better method of giving information with the help of signals which are picked up by the sense organs. But the older method might have persisted in the back-

would reward attention. For Le Bon the crowd embodies the "genius of a race," but also represents, as Borch-Jacobsen shows, "the hybrid and monstrous base" below race identity (136), and, furthermore, is associated with hysteria and femininity, since a crowd has no identity that does not come from an external "suggestion" or imitation. As in Tarde's text, a hyperinflation of mimesis besets this model. Borch-Jacobsen describes the leader of a Le Bon crowd as the incarnation of will-power and subjectivity that gives the crowd form; however, though this aesthetic and metaphysical model informs the tradition Le Bon inherited and forwarded, his text offers symptomatic complications: "The leader himself has most often started out as one of the led. He has himself been hypnotised by the idea, whose apostle he has become. It has taken possession of him to such a degree that everything outside it vanishes." Gustave Le Bon, The Crowd: A Study of the Popular Mind (London: Unwin Brothers, n.d.), 134. Also of interest is a passage in which language is imagined as emerging from the crowd's mimetic whirlpool, accompanied by a whiff of telepathy: "What, for instance, can be more complicated, more logical, than a language? Yet whence can this admirably organized production have arisen, except it be the outcome of the unconscious genius of crowds? . . Even with respect to the ideas of great men are we certain that they are exclusively the offspring of their brains? No doubt such ideas are always created by solitary minds, but is it not the genius of crowds that has furnished the thousand grains of dust forming the soil in which they have sprung up?" (9). 
ground and still be able to put itself into effect under certain conditionsfor instance, in passionately excited mobs. ${ }^{37}$

Freud's speculations on telepathy have struck many shrewd readers as being speculations on the possibility of psychoanalysis itself: "That the unconscious of the subject is the discourse of the other appears even more clearly in the studies that Freud devoted to what he called telepathy," Lacan comments. ${ }^{38}$ Jacques Derrida's claim, which we earlier heard Royle imitating, is that it is "[d]ifficult to imagine a theory of what they still call the unconscious without a theory of telepathy" ("Telepathy," 14). BorchJacobsen will suggest in a similar spirit that "the analysis of the ego (psychoanalysis)" only occurs by surpassing itself and "identifying itself with (and as) mass psychology" (The Freudian Subject, 133): a comment nicely supported by Freud's implicit link, in the passage cited above, between the unconscious and "passionately excited mobs." At the telepathic interface, the trope of the unconscious overlaps with that of the crowd. The crowd embodies a dream of direct communication, but a certain technicity, even non-humanity, remains inscribed in this dream's production, and records itself in Freud's phylogenetic and entomological speculations. As a locus of excessive communicability, telepathy places psychoanalysis within the thought of a pre-subjective, ineradicably social, and technically displaced Dasein. Telepathy, in other words, is a figure for the radically fictional, "literary" dimension of the political, and establishes undecidability as the condition of the self. For whose pathos is it, once tele-pathy has begun? And how would one ever even know whether it has begun or not?

The trope of the insect community appears to be lodged between telepathy and technics in late nineteenth-century discourse, and it surfaces with surprising frequency in Eliot's oeuvre. "When George Eliot refers to insects it is invariably in what we would call a telepathic atmosphere," Royle comments (107), drawing attention to passages in Daniel Deronda (in which ardent men of vision mold and feed "the more passive life which without them would dwindle and shrivel into the narrow tenacity of insects, un-

37. Sigmund Freud, "Dreams and Occultism," in New Introductory Lectures on Psycho-Analysis, vol. 22 of The Complete Psychological Works of Sigmund Freud, trans. and ed. James Strachey et al. 24 vols. (London: Hogarth, 1966-74), 22:55. Freud's principal other reflections on telepathy may be found in "Psychoanalysis and Telepathy" (1941 [1921]), SE 18:177-93; and "Dreams and Telepathy" (1925 [1921]), ibid., 197-220. On the overdetermined figure of the telephone see Avital Ronell, The Telephone Book: Technology - Schizophrenia - Electric Speech (Lincoln: University of Nebraska Press, 1989).

38. Jacques Lacan, "The Function and Field of Speech and Language in Psychoanalysis," in Ecrits: A Selection, trans. Alan Sheridan (New York: Norton, 1977), 55. For a study of the interplay between psychoanalysis and telepathy (and more generally, suggestion and hypnosis, against which, of course, psychoanalysis rebelled in constituting itself), see François Roustang, Psychoanalysis Never Lets Go, trans. Ned Lukacher (Baltimore: Johns Hopkins University Press, 1983), 43-65. 
shaken by thoughts beyond the reaches of their antennae" [749]) and Middlemarch (in which Dorothea dilates with Mr. Farebrother "on the possible histories of creatures that converse compendiously with their antennae, and for aught we know may hold reformed parliaments" [843]). But Royle's examples do scant justice to the force of his observation: much more remarkable telepathic insects and machines populate texts that Eliot wrote before and after her novel-writing period. In an essay on "Women in France" (1854), reflecting on the changes mass literacy had brought to the conditions of literary production, Eliot observed that the intersubjectivity of the salon had yielded to the anonymity of print, the incessant labor of reading printed texts, and the possibility of being read by them. "It is no longer the coterie which acts on literature, but literature which acts on the coterie": "In fact, the evident tendency of things to contract personal communication within the narrowest limits makes us tremble lest some further development of electric telegraph should reduce us to a society of mutes, or to a sort of insects, communicating by ingenious antennae of our own invention" (Pinney, 90). The insect here acquires overlapping connotations of technics, telepathy, and mutilation-a mutilation of voice, consequent upon a "writing" in which the subject is lost in an excessive immediacy of communication. Two years later Eliot returned to a version of this microfantasy, substituting for the insect an animated machine. In the middle of a high-powered and affirmative discussion of tradition and language in "The Natural History of German Life," an imagined reader is suddenly warned of the evils of "a patent de-odorized and non resonant language, which effects the purpose of communication as perfectly and rapidly as algebraic signs": "With the anomalies and inconveniences of historical language, you will have parted with its music and its passion ... and the next step in simplification will be the invention of a talking watch, which will achieve the utmost facility and dispatch in the communication of ideas by a graduated adjustment of ticks, to be represented in writing by a corresponding arrangement of dots. A melancholy 'language of the future'!" (Pinney, 28788 ). Here the Gothic possibilities of mutilation and prosthetic supplementation remain unactualized, but the specifically linguistic nature of the threat attains sharper focus. Common both to this passage and to the one in "Women in France," furthermore, is a temporal scheme, one we saw inverted in Freud's phylogenetic speculations, but preserved right-side-up in his allusions to future posssibilities. In Eliot the emphasis is unidirectional: the mechanical overproduction of communication belongs to the future, as though for the sympathetic imagination, as for Latimer in The Lifted Veil, the end of history could only be its own death as telepathy.

These visions may be little more than expository hiccoughs; but two decades later, after the novels, the telepathy machine was to make a more 
remarkable appearance in Eliot's oeuvre. The penultimate chapter of her last published text, Impressions of Theophrastus Such, is titled "Shadows of the Coming Race" in allusion to a science fiction story by Bulwer-Lytton, and it develops a pseudo-Darwinian hypothesis that, at the end of history, machines will supplant humanity. By evolving "conditions of self-supply, self-repair, and reproduction," technology will be able to "reproduce itself by some process of fission or budding," thus attaining the self-sufficiency of physis with parodic literalness. ${ }^{39}$ The topic is a rather incongruous one for George Eliot, as the narrator's sourly mock-serious tone for the most part confirms-but, at the fantasy's climax, that tone shades into another key, as a final surge of energy illuminates Eliot's prose:

Who-if our consciousness is, as I have been given to understand, a mere stumbling of our organisms on their way to unconscious perfection-who shall say that those fittest existences will not be found along the track of what we call inorganic combinations, which will carry on the most elaborate processes as mutely and painlessly as we are now told that the minerals are metamorphosing themselves continually in the dark laboratory of the earth's crust? Thus this planet may be filled with beings who will be blind and deaf as the inmost rock, yet will execute changes as delicate and complicated as those of human language and all the intricate web of what we call its effects, without sensitive impression, without sensitive impulse: there may be, let us say, mute orations, mute rhapsodies, mute discussions, and no consciousness there even to enjoy the silence. (Theophrastus Such, 254-55)

Without entirely losing its satiric edge, the text generates a moment of epistemological grappling worthy of those troubling the major turns of Middlemarch or Daniel Deronda: we hear in this paragraph something of the "rhythm of the sublime" that Hertz observes to be guiding Dorothea's attempt to internalize the alien codes of Rome $(E L, 90)$. Even more remarkably, the anaphoric pulse of sublime language is attained by way of nothing less than the figure of "human language" itself. Something strange and plural, first called "processes," then "changes," is likened first to geological metamorphosis, then, more insistently, to language and its "effects," to

39. George Eliot, Impressions of Theophrastus Such (Edinburgh: Blackwood, n.d.), 250, 253; subsequent references are to this edition. The metaphysical inflection of technology has been discussed elsewhere, particularly in the previous chapter, but we may recall here Heidegger's definition of the contrast between techne and physis: the former involves an efficient cause - the artist or artisan-whereas that which is physis is "poiesis in the highest sense" because it "has the bursting open belonging to bringing-forth, e.g., the bursting of a blossom into bloom, in itself (en heautoi)." Martin Heidegger, The Question concerning Technology and Other Essays, trans. William Lovitt (New York: Harper and Row, 1977), 10. 
language as trope and performance-the substitution of such technical terms would be entirely in the spirit of this passage. The most extraordinary representations barely suffice as Eliot's text seeks words for the strangeness of words. Here, at history's end, the telepathy machine has become sheer "tele," devoid of "pathos," an impossible trope-machine cut off from the phenomenal world but possessed of "effects" nonetheless. These uncannily neutral "processes" and "changes" are at once objectless and-since the machines lack all consciousness - subjectless: they describe the formality of a substitutive process apart from all meaning or intention. Radically a-referential in their formalized perfection, the machines might be said to act upon the world with the efficacity of a total technology, were it not for the loss of sense suffered by any notion of "action" in this scenario. The machines "execute changes" interpretable as linguistic "effects"; but in the absence of agent and object this effectivity becomes a paradoxical catechresis, legible only when we impute to it the meaning it disallows. However necessary it may be to conclude that "language" "acts," one cannot claim to have said anything meaningful in saying so-except by mistake.

Theophrastus Such is a strange text, one that Eliot's twentieth-century critics have largely preferred to ignore. It has, indeed, arguably proved the least welcome of all her works, lacking the vivid Gothicism of "The Lifted Veil," or the narrative and thematic interest of "Brother Jacob" and the poetry. Worst of all, it comes at the end of a career which can certainly be closed off in more satisfying fashion with the grander ambiguities of Daniel Deronda; one is instead presented with the spectacle of an author turning from her most courageously experimental novel to an atavistic genre and a tonality at once bitter and ponderous. But within the context of Eliot's oeuvre this text also presents itself as curiously overdetermined. The European revival of Theophrastus can be traced to Isaac Casaubon's publication of the Greek text with Latin translation and commentary in 1592; this, according to Gordon Haight, is in fact the edition that George Eliot used. 40 In her rewriting of it, Eliot touches most of the generic stops of the Theophrastan character sketch as it descends from La Bruyère and Addison and Steele: a didactic concern for decorum; a survey of the petty faults of an urban bourgeois class; a wide-ranging overview of society spun around the castigation of exemplary, allegorically named "characters." But in Eliot's hands these generic directives assemble a world saturated with conversation, writing, and publishing: nearly every sketch in Theophrastus Such concerns authorship, injury, and the dangerously volatile circulation of intellectual property. Eliot's own Mr. Casaubon had fought his ghostly textual

40. See Gordon Haight, "Poor Mr Casaubon," in George Eliot's Originals and Contemporaries: Essays in Victorian Literary History and Biography, ed. Hugh Witemeyer (Ann Arbor: University of Michigan Press, 1992), 31. 
battles with critics bearing Theophrastan names (Carp, Pike, Tench); in Theophrastus Such Casaubon's anxious scholarly jousting inflates into the guiding principle of an urban, fin-de-siècle bachelor world in which quarter is rarely given or received. ${ }^{41}$ Nearly every inhabitant of this world is a failed or failing author, suffers from the "disease of magnified selfimportance belonging to small authorship" (Theophrastus Such, 224), and takes eager note of the shortcomings of everyone else: the first-person male narrator adds to these qualities that of slightly strident moralist, pronouncing in Juvenalian fashion on the debasement of the nation's "moral currency." In content and tone as well as in the conventions of its genre, the text turns away from or falls short of Eliotic sympathy; it is correspondingly hard to read.

But in a sense sympathy has withered under the weight of its own overperformance: it has shrunk thanks to its ungovernable inflation into a telepathic hypercirculation of signs. In the commodified and competitive world of Theophrastus Such, telepathy becomes the problem of plagiarism. One of the character sketches composing this strange, gloomy text stars a plagiarist who steals language from essays such as "The Natural History of German Life" as he expatiates on "that growing preparation for every epoch through which certain ideas or modes of view are said to be in the air, and, still more metaphorically speaking, to be inevitably absorbed, so that every one may be excused for not knowing how he got them" (158). In this sketch the narrator excoriates the plagiarist for his ethical levity; but curiously enough, after giving vent to his language-machine fantasy in "Shadows of the Coming Race," the narrator will plagiarize the plagiarist: the premises of his telepathy-fantasy, he says, "seem to be flying about in the air with other germs, and have found a sort of nidus among my melancholy fancies. Nobody really holds them" (249). This excuse, however, does not prove entirely airtight (even though "hardly any accusation is more difficult to prove, and more likely to be false, than that of a plagiarism" [163]). Like the narrator of the earlier sketch, Eliza Savage had no patience with such fudging; she wrote to Samuel Butler that "the only bit in the least bit readable [in Theophrastus Such] is a crib from Erewhon - a most barefaced

41. On the bachelor in nineteenth-century British narrative, see Eve Sedgwick, "The Beast in the Closet: James and the Writing of Homosexual Panic," in her Epistemology of the Closet (Berkeley: University of California Press, 1990), 182-212, especially 188-95: "Where the Gothic hero had been solipsistic, the bachelor hero is selfish. Where the Gothic hero had raged, the bachelor hero bitches. Where the Gothic hero had been suicidally inclined, the bachelor hero is a hypochondriac" (188-89). These comments capture at least part of the ambience of Theophrastus Such, as do Sedgwick's witty reflections on the "feline gratuitousness of aggression" in the bachelor world: "At odd moments one is apt to find kitty's unsheathed claws a millimeter from one's own eyes.... When one bachelor consults another bachelor about a third bachelor, nothing is left but ears and whiskers" (192). 
crib." 42 Butler wrote in turn to his sister of the "compliment" Eliot had paid him in introducing "a certain chapter on machines": "I had the satisfaction that great minds had thought alike-that was all; but the resemblance is so close that there can be no doubt where she drew it from." 43 Eliot's biographer, Gordon Haight, suggests that "the idea had probably been discussed with friends like Spencer while Lewes was writing the section on 'Animal Automatism' in Problems"; 44 and we are not likely to learn more about how this particular airborne germ blew into George Eliot's mind. It is, however, (nearly) indisputable that her title alludes to the text that Butler himself had been suspected of plagiarizing; he had gone to some pains in the preface to the second edition of Erewhon to prove that his novel had been written before "the first advertisement of [Bulwer-Lytton's] 'The Coming Race' appeared." 45 The ballooning question of plagiarism, within and without Theophrastus Such, enacts the predicament which embitters this text but which also made the novels possible. Sympathy's condition of possibility is its own destruction; or, put another way, sympathy's reiterated, fragile survival occurs thanks to a capacity for error which Eliot's texts at various times call writing, melodrama, gambling, plagiarism, or telepathy, and which, in the rhetorical terminology proper to a critique of aesthetics, may be called irony.

42. Geoffrey Keynes and Brian Hill, eds., Letters Between Samuel Butler and Miss E. M. A. Savage (1871-1885) (London: Jonathan Cape, 1935), 210.

43. Daniel F. Howard, ed., The Correspondence of Samuel Butler with His Sister May (Berkeley: University of California Press, 1962), 86.

44. Gordon S. Haight, George Eliot: A Biography (New York: Oxford University Press, 1968), 522. 45. "'Erewhon' was finished with the exception of the last twenty pages and a sentence or two inserted from time to time here and there throughout the book, before the first advertisement of 'The Coming Race' appeared. ... [B]eing in an out of the way part of Italy, [I] never saw a single review of 'The Coming Race', nor a copy of the work. On my return, I purposely avoided looking into it until I had sent back my last revises to the printer." Samuel Butler, Erewhon; or, Over the Range, ed. Hans-Peter Breuer and Daniel F. Howard (Newark: University of Delaware Press, 1981), 41. The Coming Race had been published anonymously late in 1871, but was known to be by Bulwer-Lytton; Erewhon was also published anonymously, and its initial success, as Butler suspected, was mostly due to its being taken as a sequel to The Coming Race. When the Athenaeum of 25 May 1872 revealed Butler's authorship, sales dropped 90 percent. 